\title{
The Surface Properties of Hydrophobic Silica Gels Treated with $n$-Pentanol or Benzyl Alcohol by Means of Vapor-Phase Adsorption and of Heat of Wetting Measurement
}

\author{
Hiroshi Utsugi and Shigeoki Nishimura \\ Department of Applied Science, Faculty \\ of Engineering, Tohoku University*
}

\begin{abstract}
The surface properties of silica gels treated with $n$-pentanol or benzyl alcohol accompanying with various numbers of surface adsorptive group were investigated from the adsorption of argon at $77^{\circ} \mathrm{K}$, heptane at $273^{\circ} \mathrm{K}$ and water vapor at $288^{\circ} \mathrm{K}$, and also the heat of wetting into $n$-heptane or water at $288^{\circ} \mathrm{K}$, respectively. The surface of the treated silica gels was confirmed to be composed of the hydrophilic and hydrophobic surfaces. In the formation of monolayer, the water vapor could not be adsorbed on the hydrophobic surface, but on the hydrophilic surface, whilst argon or heptane could be adsorbed on both surfaces. The $n$-heptane was found not to be adsorbed on the inner surface of the micropores with radius less than a molecular size of $n$-heptane. On this aspect. the surface areas of surface-treated silica gels obtained from argon, $n$-heptane and water vapor adsorption, $\sum_{\mathrm{HRSK}}^{\mathrm{Ar}}, \sum_{\mathrm{HRSK}}^{\mathrm{hep}}, \sum_{\mathrm{HRSK}}^{\mathrm{H}_{2} \mathrm{O}}$ were represented by the following equations, respectively. $\sum_{\mathrm{HRSK}}^{\mathrm{Ar}}$ $=\sum_{\mathrm{SK}}^{\mathrm{Ar}}-\left(\mathrm{N}_{\mathrm{OH}}^{\mathrm{C}} / \mathrm{N}_{\mathrm{R}}\right) \sigma_{\mathrm{OH}} \cdot \mathrm{N}_{\mathrm{R}}, \sum_{\mathrm{HRSK}}^{\text {hep }}=\sum_{\mathrm{SK}}^{\text {hep }}-\left(\mathrm{N}_{\mathrm{OH}}^{\mathrm{C}} / \mathrm{N}_{\mathrm{R}}\right) \sigma_{\mathrm{OH}} \cdot \mathrm{N}_{\mathrm{R}}$ and $\sum_{\mathrm{HRSK}}^{\mathrm{H}_{2} \mathrm{O}}=\sum_{\mathrm{SK}}^{\mathrm{H}_{2} \mathrm{O}}-\left(1+\mathrm{N}_{\mathrm{OH}}^{\mathrm{C}} / \mathrm{N}_{\mathrm{R}}\right)$ $\sigma_{\mathrm{OH}} \mathrm{N}_{\mathrm{R}} \cdot$ Where $\sum_{\mathrm{SK}}^{\mathrm{X}}$ is the surface area of the native silica gel obtained from adsorption of $\mathrm{X}$ and $\mathrm{N}_{\mathrm{OH}}^{\mathrm{C}}, \mathrm{N}_{\mathrm{R}}$ and $\sigma_{\mathrm{OH}}$ are the numbers of unreacted silanol caged in the micropores which were unable to afford adsorption site for any adsorbate, numbers of surface adsorptive group and the cross sectional area of silanol. These relations were confirmed to be reasonable in comparison with the experimental results. The pore structure of the surfacetreated silica gels was discussed on the basis of the capillary condensation theory for the adsorption in the region of higher relative pressure. The heat of wetting on surface-treated silica gels, $\Delta H_{i} \mathrm{x}$ (erg/g of silica gel) in which $\mathrm{X}$ designates the wetting medium, was divided into two terms, i. e., interaction between $\mathrm{X}$ and hydrophilic or hydrophobic surfaces by using the relation, $\Delta H_{i}{ }^{\mathrm{X}}=\Delta h_{i}{ }^{\mathrm{R}-\mathrm{X}} \sum_{\mathrm{R}}^{\mathrm{X}}+\Delta h_{i}{ }^{\mathrm{OH}-\mathrm{X}} \sum_{\mathrm{OH}}^{\mathrm{X}}$, where $\sum_{\mathrm{R}}^{\mathrm{X}}$ and $\sum_{\mathrm{OH}}^{\mathrm{X}}$ are the surface areas from the adsorption isotherms of $\mathrm{X}$ on the hydrophobic surface indicated by subscript $R$, and on the hydrophilic surface indicated by subscript $O H$ which is mainly due to the unreacted surface silanols and afford the adsorption site for $\mathrm{X}$, and also $\Delta h_{i}{ }^{\mathrm{R}-\mathrm{X}}$ and $\Delta h_{i}{ }^{\mathrm{OH}-\mathrm{X}}$ are the heat of immersion per unit area of hydrophobic surface indicated by superscript $\mathrm{R}-\mathrm{X}$, or hydrophilic surface indicated by $\mathrm{OH}-\mathrm{X}$. Thus obtained $\Delta h_{i}{ }^{\mathrm{R}-\mathrm{X}}$ and $\Delta h_{i}{ }^{\mathrm{OH}-\mathrm{X}}$ showed reasonable values, comparing with the available data on purely hydrophilic or hydrophobic surfaces. Accordingly, it was pointed out to be still questionable that the heat of wetting on the composed surface of either hydrophilic or hydrophobic was usually obtained by dividing the liberated heat by the apparent surface area obtained from the nitrogen or argon adsorption.
\end{abstract}

* Aoba, Aramaki-aza, Sendai-shi, Japan

$\overline{2[1]}$ 


\title{
蒸気吸着および湿潤熱によるペンタノール, ベンジル アルコール処理シリカゲル表面特性の検討
}

\author{
宇津木 弘* ・西 村 成 興**
}

要旨

付着基数を種々に变えたペンタノール，ベンジルアルコール処理シリカゲルの表面特性 が $77^{\circ} \mathrm{K}, 273^{\circ} \mathrm{K}$ ヘプタン, $288^{\circ} \mathrm{K}$ 水蒸気吸着と $278^{\circ} \mathrm{K}$ ヘプタン脑よび水への湿潤熱から 検討された。表面処理シリカゲルは親油性, 親水性表面から成り, 単分子層形成過程では 水蒸気は親水性表面にのみ吸着し, 親油基には吸着しない。これに反しアルゴン括よびへ プタンはそのいずれの表面にも吸着するが， ヘプタンはその分子径の大きなために，微小 径空孔内の表面には吸着し得ない。この観点から処理シリカゲルのアルゴン, ヘプタン, 水蒸気吸着表面積, $\sum_{\mathrm{HRSK}}^{\mathrm{Ar}}, \sum_{\mathrm{HRSK}}^{\mathrm{hep}}, \sum_{\mathrm{HRSK}}^{\mathrm{H} 2 \mathrm{O}}$ はそれぞれ次式で示されることが認めら れ, 実験的にも確められた。 $\sum_{\mathrm{HRSK}}^{\mathrm{Ar}}=\sum_{\mathrm{SK}}^{\mathrm{Ar}}-\left(\mathrm{N}_{\mathrm{OH}}^{\mathrm{C}} / \mathrm{N}_{\mathrm{R}}\right) \sigma_{\mathrm{OH}} \cdot \mathrm{N}_{R} ; \sum_{\mathrm{HRSK}}^{\mathrm{H}_{2} \mathrm{O}}=\sum_{\mathrm{SK}}^{\mathrm{H}_{2} \mathrm{O}}-(1+$ $\left.\mathrm{N}_{\mathrm{OH}}^{\mathrm{C}} / \mathrm{N}_{\mathrm{R}}\right) \sigma_{\mathrm{OH}} \cdot \mathrm{N}_{\mathrm{R}} ; \sum_{\mathrm{HRSK}}^{\mathrm{hep}}=\sum_{\mathrm{SK}}^{\text {hep }}-\left(\mathrm{N}_{\mathrm{OH}}^{\mathrm{C}} / \mathrm{N}_{\mathrm{R}}\right) \sigma_{\mathrm{OH}} \cdot \mathrm{N}_{\mathrm{RO}}$ ここに $\sum_{\mathrm{SK}}^{\mathrm{X}}$ は未処理シリカゲル の吸着質Xで求められた表面積であり， $\mathrm{N}_{\mathrm{OH}}^{\mathrm{C}}, \mathrm{N}_{\mathrm{R}}$ 扎よび $\sigma_{\mathrm{OH}}$ はそれぞれ付着基で扮拉わ れて, いずれの吸着質でも吸着点となり得ない微小空孔に閉じこめられた未反応シラノ一 ル数, 付着基数执よびシラノールの分子断面積である。この関係で求められる多くの種類の 付着基についての $\left(\mathrm{N}_{\mathrm{OH}}^{\mathrm{C}} / \mathrm{N}_{\mathrm{R}}\right) \sigma_{\mathrm{OH}}$ を付着基に相当するアルコールの分子断面積に対しプロ ットすると, 水酸基の分子断面積に相当する部分で零となる一定な傾斜を持つ直線関係が 得られる。この直線の傾斜は原料シリカゲルの性質により異なる。処理シリカゲルの湿潤 熱はこのような親水性, 親油性表面への湿潤液の相互作用として検討し, 合理的な值を得 た。湿潤熱を未処理または処理シリカゲルのアルゴンまたは窒素表面積で割り, 単位面積 当たりで求めることはこのような複合表面ではな牤疑問の余地があり，これらは別々に分 離して求められるべきであろら。

\section{1. 緒論}

シリカゲルは，これとアルコールあるいはアルコール のヘキサン溶液をオートクレーブ中で高温高圧下で反応 させることにより表面処理することができる1,2)。この ような表面処理法はフェノール類のアセトン溶液につい ても有効である3)。これら表面処理シリカゲルの付着基 が親油基の場合には, 元来親水性であるシリカゲル表面 は親油性を示すようになるし，付着基に親水基を持つ場 合には親水性を示すことが，二相に分離する混合分散媒

昭和 49.11 .5 受理

* 東北大学工学部 仙台市荒巻字青葉

** 現在 日立研究所 茨城県日立市久慈町

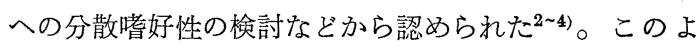

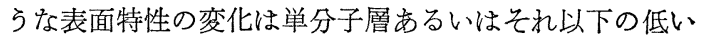
被覆での付着基で示されていることが，付着基数の検討 から確められた。赤外線収吸スペクトル5,6) とか熱分 析 $^{6,7)}$ による付着基の同定和よび熱的性状の検討から, また加水分解など溶離された付着基の定性分析 ${ }^{2,3)}$ とか ら, これら付着基は単なる吸着アルコールではなく, エ ステル化といったよらな反応で結合しているものと認め られた。したがってこれらの付着基は安定しており, シ リカゲルを表面処理した後での新たな表面を形成してい ると考えられるであろら。

このよらな表面処理シリカゲルの水, ヘプタン, アル ゴン表面積はそれぞれ異なった表面積を与えるから，処 
理シリカゲルの表面は親水, 親油性表面の複合表面から 成ると考光, この観点から処理シリカゲルへの水, ヘプ タンの湿潤熱を合理的に説明することができた ${ }^{8,9)}$ 。種 々な濃度のアルコールのーキサン溶液でシリカゲルを同 様な手法で処理すると, 付着基数を種々に変光たシリカ ゲルを調整することができる2)。アルゴン表面積は一般 飞親水, 親油性表面のいずれについても妥当な表面積を 与兄ることが知られている ${ }^{8 \sim 10)}$ 。そこでこのようなシリ カゲルのアルゴン表面積を付着基数に対して検討する と, 付着基は微小空孔内の未反応な近接するシラノール を被覆して括り，付着基当たりのこの数は付着基数にか かわらずほぼ一定していることが認められ，アリルアル コール，ペンダノール処理の場合につき報告された ${ }^{2)}$ 。 このような表面処理シリカゲルの表面特性は吸着熱11) と か蒸気吸着 ${ }^{11,12)}$ で検討した報告例は認められるが，付着 基数を種々に变えた試料について親水性あるいは親油性 蒸気で比較検討した例は少ない。したがって親水性, 親 油性両方の性質を適宜な割合で持つ表面へのアルゴン， 水蒸気, ヘプタンの吸着とか, これら表面への水, ヘプ タンの湿潤熱とから，表面の性質を検討することは與味 深い。本報告ではこれらの点を検討する。

\section{2. 突 験 方 法}

測定に使用した試料は市販クロマト用シリカゲルSK2 とこれをペンタノール（略記号A）のみ，あるいはこれ のへキサン溶液で処理した HASK 2 と ASK $2 \mathrm{n}(\mathrm{n}=1$ 〜6) 特よび同じ製品であるが，Lot No. の異なるSK 3 とこれをベンジルアルコール（略記号 BZ）のヘキサン 溶液で処理した BZSK $3 \mathrm{n}^{\prime}\left(\mathrm{n}^{\prime}=1 \sim 5\right)$ と BZSK 35 を 加水分解して付着基を一部溶解した BZSK $35\left(\mathrm{H}_{2} \mathrm{O}, 1\right)$, BZSK 35 (aq. Acetone, 5 hrs) と BZSK 35 (aq. Acetone, $15 \mathrm{hrs)}$ で㐫る。処理試料の記号中Hはアルコールのみで 処理した場合，これのないのはへキサン溶液で反応した 場合を示す。また n， n' は実験番号である。表面処理

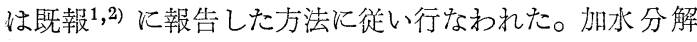
は $\mathrm{H}_{2} \mathrm{O}$ の夕，または $8 \%$ アアセトン水溶液で 5 または 15 時間煮沸することによりなされた。またこれらの試料 は固結を防止するため, 加水分解液と分離後アセトンで 洗浄後室温で乾燥したものである。吸着平衡は既報7,8) の装置牤上び方法に従った。吸着質はアルゴン, 水蒸気, ヘプタンで㐫り，測定温度はそれぞれ $77^{\circ} \mathrm{K}, 288^{\circ} \mathrm{K}$ 特よび $273^{\circ} \mathrm{K}$ である。蒸気吸着には同一試料を用いた。すなお らへプタン吸着平衡を飽和蒸気压まで測定後排気(130 ${ }^{\circ} \mathrm{C}, 3 \times 10^{-5}$ Torr), 水蒸気吸着平衡を測定した。グリー スの影響を避けるため粶気吸着測定装置にはグリースコ
ックの代りに水銀カット，グリース摺り合わせの代りに 水銀シールを用いた。湿潤熱の測定には応用電気研究所 製双子型微少熱量計を用いた。測定温度は $25^{\circ} \mathrm{C}$ で測定 方法は前報 ${ }^{8,9}$ の方法に従った。湿潤液は ASK 2 につい てはへプタン和よび水であり, BZSK 3 についてはへプ タンである。

\section{3. 実 験 結 果}

ASK 2, BZSK 3 ヘのアルゴン, 水蒸気, ヘプタン吸 着等温線を各々図-1 に示した。これから求められる BET表面積はそれぞれの付着基数と共に表-1 に示した。 同表にはそれぞれの計算に用い分子断面積も併示した。 これら試料の水, 油のように二相に分離する混合分散媒 への分散㬐好性とか，水岁るいはへプタンへの分散性は

Table 1. The numbers of surface group of surface-treated silica gels and surface areas of the original and surface- treated silica gels obtained from the adsorption isotherms of argon, water and $n$-heptane

(A) Silica gels treated with $n$-pentanol

\begin{tabular}{l|c|c|c|c}
\hline Sample & $\begin{array}{c}\text { Numbers } \\
\text { of } \begin{array}{c}\text { surface } \\
\text { group } \\
10^{-21}\left(\mathrm{~g}^{-1}\right)\end{array}\end{array}$ & $\begin{array}{c}\text { Argon } \\
\sigma=14 \AA^{2} \\
\sum^{\mathrm{Ar}} \\
\left(\mathrm{m}^{2} / \mathrm{g}\right)\end{array}$ & $\begin{array}{c}\text { Surface } \\
\text { areas } \\
n \text {-heptane } \\
\sigma=43 \AA^{2} \\
\sum^{\mathrm{hen}}\left(\mathrm{m}^{2} / \mathrm{g}\right)\end{array}$ & $\begin{array}{c}\text { Water } \\
\sigma=10.5 \AA^{2} \\
\sum^{\mathrm{H}_{2} \mathrm{O}} \\
\left(\mathrm{m}^{2} / \mathrm{g}\right)\end{array}$ \\
\hline SK 2 & & 567 & 437 & 565 \\
ASK 21 & 0.95 & 351 & 269 & 220 \\
ASK 22 & 1.14 & 306 & 191 & 168 \\
ASK 23 & 1.23 & 267 & 184 & 101 \\
ASK 24 & 1.30 & 248 & 162 & 159 \\
ASK 25 & 1.14 & 226 & 159 & 133 \\
ASK 26 & 0.99 & 326 & 199 & 144 \\
HASK 2 & 1.22 & 248 & 167 & 76 \\
\hline
\end{tabular}

(B) Silica gels treated with benzyl alcohol

\begin{tabular}{|c|c|c|c|c|}
\hline Sample & 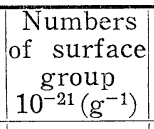 & $\sum_{\left(\mathrm{m}^{2} / \mathrm{g}\right)}^{\mathrm{Ar}}$ & $\begin{array}{l}\sum^{h e_{p}} \\
\left(m^{2} / g\right)\end{array}$ & $\begin{array}{l}\sum^{\mathrm{H}_{2} \mathrm{O}} \\
\left(\mathrm{m}^{2} / \mathrm{g}\right)\end{array}$ \\
\hline SK 3 & & 561 & 413 & 549 \\
\hline BZSK 31 & 1.44 & 169 & 195 & 111 \\
\hline BZSK 32 & 0.92 & 263 & 210 & 212 \\
\hline BZSK 33 & 0.84 & 296 & 222 & 181 \\
\hline BZSK 34 & 1.11 & 248 & 195 & 124 \\
\hline BZSK 35 & 1.00 & 256 & 158 & 133 \\
\hline BZSK $35\left(\mathrm{H}_{2} \mathrm{O}\right)$ & 0.32 & 470 & 360 & 425 \\
\hline $\begin{array}{l}\text { BZSK } 35 \\
\left(\begin{array}{l}\text { aq. acetone } \\
15 \text { hrs }\end{array}\right)\end{array}$ & 0.72 & 334 & 236 & 205 \\
\hline
\end{tabular}



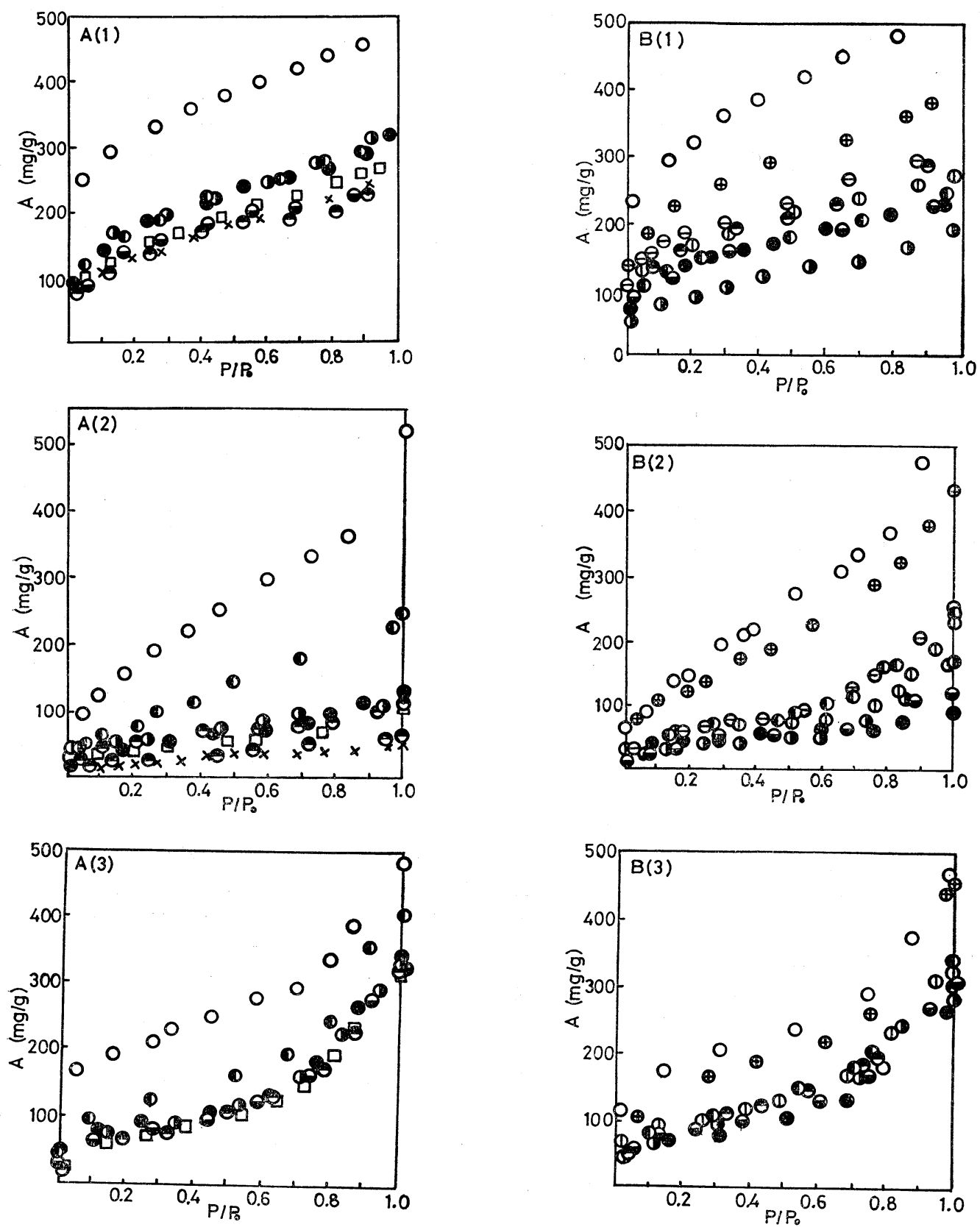

Fig. 1. Adsorption isotherms of argon, water and $n$-heptane on the native and surface-treated silica gels

(A) Silica gels treated with $n$-pentanol

(1) Argon at $77^{\circ} \mathrm{K},(2)$ Water at $288^{\circ} \mathrm{K}$, and (3) $n$-Heptane at $273^{\circ} \mathrm{K}$

:SK 2 ; :ASK 21 ; :ASK 22 ; : ASK 23 ; ASK $24 ; \square:$ ASK 25 ; ASK 26 ; $\times$ : HASK 2

(B) Silica gels treated with benzyl alcohol

(1) Argon at $77^{\circ} \mathrm{K}$, (2) Water at $288^{\circ} \mathrm{K}$, and (3) $n$-Heptane at $273^{\circ} \mathrm{K}$

: SK 3 ; : BZSK 31 ; $:$ BZSK 32 ; BZSK $33 ; \ominus$ : BZSK $34 ;$; BZSK $35 ;$ BZSK $35\left(\mathrm{H}_{2} \mathrm{O}\right) ;(1)$ : BZSK 35 (aq. aceton $5 \mathrm{hrs}$ ) ; $\ominus$ : BZSK 35 (aq. acetone $15 \mathrm{hrs}$ ) 
Table 2. The dispersive property of the native and surface-treated silica gels into water, $n$-heptane and the mixed media immiscible with each other like oil and water

(A) Silica gels treated with $n$-pentanol

\begin{tabular}{l|c|c|c}
\hline Sample & Water & $n$-Heptane & $n$-Heptane/Water \\
\hline SK 2 & $\bigcirc$ & $\bigcirc$ & $\times / \bigcirc$ \\
ASK 21 & $\bigcirc$ & $\bigcirc$ & $\times / \bigcirc$ \\
ASK 22 & $\times$ & $\bigcirc$ & $\bigcirc / \times$ \\
ASK 23 & $\times$ & $\bigcirc$ & $\bigcirc / \times$ \\
ASK 24 & $\times$ & $\bigcirc$ & $\bigcirc / \times$ \\
ASK 25 & $\times$ & $\bigcirc$ & $\bigcirc / \times$ \\
ASK 26 & $\triangle$ & $\bigcirc$ & $\times / 0^{*}$ \\
HASK 2 & $\times$ & $\bigcirc$ & $\bigcirc / \times$ \\
\hline
\end{tabular}

(B) Silica gels treated with benzyl alcohol

\begin{tabular}{l|c|c|c}
\multicolumn{1}{c|}{ Sample } & Water & $n$-Heptane & $n$-Heptane/Water \\
\hline SK 3 & $\bigcirc$ & $\bigcirc$ & $\times / \bigcirc$ \\
BZSK 31 & $\times$ & $\bigcirc$ & $\bigcirc / \times$ \\
BZSK 32 & $\times$ & $\bigcirc$ & $\bigcirc / \times$ \\
BZSK 33 & $\triangle$ & $\bigcirc$ & $\bigcirc / \times$ \\
BZSK 34 & $\times$ & $\bigcirc$ & $\bigcirc / \times$ \\
BZSK 35 & $\times$ & $\bigcirc$ & $\bigcirc / \times$ \\
BZSK 35(H2) & $\bigcirc$ & $\bigcirc$ & $\times / \bigcirc$ \\
BZSK 35 & $\triangle$ & $\bigcirc$ & $\triangle / \triangle$ \\
(aq. acetone & & & \\
5 hrs & & & $\triangle / \triangle$ \\
BZSK 35 & $\triangle$ & 0 & \\
(aq. acetone & & & \\
15 hrs & & & \\
\hline
\end{tabular}

* : Flocculate into the interface after shaking, but disperse into water gradually

$\bigcirc: \operatorname{good} ; \times:$ bad $\triangle \triangle:$ good, if anything

表-2 に示した。ASK 2 への水拉よびへプタンの湿潤熱 と BZSK 3 へのヘプタンの湿潤熱を表-3に示した。

\section{4. 結 果の検討}

\section{1 吸着等温平衡}

図-1 に示されるよらに ASK $2 \mathrm{n}$, BZSK $3 \mathrm{n}$ の $77^{\circ} \mathrm{K}$ アルゴン吸着等温線は BET 分類での I 型に属するが, 単分子層完成後, 比圧増加に伴ない飽和する傾向を示 す。しかしこれらは単純な Langmuir 型ではなく, 中 間比圧およびそれ以上の領域でも吸着量が単調に増加す る Hüttig 型等温線を示す ${ }^{13)}$ 。また $273^{\circ} \mathrm{K}$ ヘプタン吸 着等温線は BET 分類IIまたはN 型に属する。これらは いずれもほぼ全比圧範囲にわたり未処理試料の吸着量よ り小さく, この減少の程度は処理程度に応じる傾向があ る。 $288^{\circ} \mathrm{C}$ 水蒸気吸着等温線は上記二者とは著しく異な り，未処理シリカゲルでは BET II 型を示すが， ASK
Table 3. The heat of wetting of water and $n$-heptane on surface-treated silica gels with various numbers of surface group

(A) Silica gels treated with $n$-pentanol

\begin{tabular}{|c|c|c|c|c|c|}
\hline \multirow{2}{*}{ Sample } & \multirow{2}{*}{\begin{tabular}{|c|} 
Numbers \\
of surface \\
group \\
$\mathrm{N}_{\mathrm{R}} \times 10^{-21}$ \\
$\left(\mathrm{~g}^{-1}\right)$
\end{tabular}} & \multicolumn{2}{|c|}{$\Delta H_{i} \mathrm{H}_{2} \mathrm{O}$} & \multicolumn{2}{|c|}{$\Delta H_{i}^{\mathrm{h} \theta_{\mathrm{p}}}$} \\
\hline & & $\begin{array}{c}\times 10^{-8} \\
(\mathrm{erg} / \mathrm{g})\end{array}$ & $\left(\mathrm{erg} / \mathrm{cm}^{2}\right)$ & $\begin{array}{r}\times 10^{-8} \\
(\mathrm{erg} / \mathrm{g})\end{array}$ & $\left(\mathrm{erg} / \mathrm{cm}^{2}\right)$ \\
\hline SK 2 & & 11. 08 & 197 & 4.06 & 93 \\
\hline ASK 21 & 0.96 & 7.73 & 351 & 4.72 & 176 \\
\hline ASK 23 & 1. 23 & 4. 18 & 414 & 3.60 & 196 \\
\hline ASK 24 & 1.30 & 4.58 & 265 & 4.00 & 247 \\
\hline ASK 25 & 1. 14 & 4.20 & 316 & 2. 97 & 187 \\
\hline ASK 26 & 0.99 & 4.33 & 301 & 2.70 & 136 \\
\hline HASK2 & 1.22 & 2.03 & 268 & 2.85 & 171 \\
\hline
\end{tabular}

(B) Silica gels treated with benzyl alcohol

\begin{tabular}{l|c|c|c}
\hline \multirow{2}{*}{ Sample } & $\begin{array}{c}\text { Numbers of } \\
\text { surface group } \\
\mathrm{N}_{\mathrm{R}} \times 10^{-21}\left(\mathrm{~g}^{-1}\right)\end{array}$ & \multicolumn{2}{|c}{$\Delta H_{i}^{\mathrm{hep}}$} \\
\cline { 3 - 4 } & & 5.41 & 131 \\
$(\mathrm{erg} / \mathrm{g})$ & $\left(\mathrm{erg} / \mathrm{cm}^{2}\right)$ \\
\hline SK 3 & 1.14 & 2.10 & 108 \\
BZSK 31 & 0.92 & 4.00 & 191 \\
BZSK 32 & 0.84 & 4.01 & 93 \\
BZSK 33 & 1.11 & 3.32 & 175 \\
BZSK 34 & 1.00 & 2.78 & 175 \\
BZSK 35 & 0.32 & 4.70 & 131 \\
BZSK 35 $\left(\mathrm{H}_{2} \mathrm{O}\right)$ & & &
\end{tabular}

$2 \mathrm{n}$ では処理程度の比較的小さい ASK 21 で BET II 型 であるのに対し，他は全て BET I 型である。表-2 に 示されるよらに BET II 型を示すこの試料は親水性であ るが, BET I 型を示す他の試料は親油性である。また ベンジルアルコール処理シリカゲルでも水蒸気吸着等温 線の形は付着基数の大きいものでは BET I 型である。 付着基数が $0.7 \times 10^{21} \mathrm{~g}^{-1}$ 程度でも高比圧部での立ら上 りが幾分か認められるが，通常の BET II 型にみられる ほど, 高比圧での吸着量の立ち上りは認められない。特 に加水分解で付着基を $0.3 \times 10^{21} \mathrm{~g}^{-1}$ 程度にまで溶離し た BZSK $35\left(\mathrm{H}_{2} \mathrm{O}\right)$ の赤外線吸収スペクトルには付着基 特性吸取強度の減少が認められ, これに対して付着水に よる $3,500 \mathrm{~cm}^{-1}$ の吸収の著しい増大が示された4)。こ の試料の水蒸気吸着は単分子吸着量と共に高比圧部での 吸着量の急増が著しく, 未処理シリカゲル SK 3 のそれ に近づくことがわかる。表-2 に示されるようにこの場 合も, BZSK $35\left(\mathrm{H}_{2} \mathrm{O}\right)$ 以外はほぼ親油性であり，水蒸 気吸着等温線の形が BET I 型に近いものほど親油性で あることを示している。これらのことは水蒸気吸着等温 線の高比圧部での吸着量の増加を示す試料は親水性を示 
すと考兄られ，水蒸気吸着等温線からも分散嗜好性を検 討できることを示していると考兄られる。また加水分解 で付着基を溶離した BZSK $35\left(\mathrm{H}_{2} \mathrm{O}\right)$ の水蒸気吸着等温 線が未処理シリカゲル SK 3 のそれに近づくのであるか ら, この表面処理の過程が粉体の毛管分布とか, 粒径な ぞの基本的な性質には大きな変化は与兄ていないと認め らるであろら。

図-1 に示されるように，親油性の程度の大きな試料 への水蒸気吸着等温線でも, 等温線は BET V 型を示さ ず，比圧の小さな部分での立ち上りのあること拈よび等 温線の形が BET I 型でも単純な Langmuir 型ではな く, Hüttig 型であることは, これら処理シリカゲルで あ水蒸気が吸着すること，すなわち处理シリカゲルの表 面は親水性, 親油性表面から成ることを示唆していると 考兄られる。

\section{2 表面積}

微粉体のアルゴンによる表面積は表面が親油性（活性 炭, グラファイト等) とか親水性（金属酸化物）である かにかかわらず，窒素と同様に妥当な表面積を与兄るこ とが報告されている14,15)。またへプタンによる表面積 も, 親油性とか親油性表面のいずれに対しても妥当な表 面積を与えるが，分子径の大きいことから小径毛管を多 数有するような粉体の場合にはアルゴンまたは窒素表面 積より小さな表面積を与える傾向のあることが認められ ている16)。したがって表-1 に示された SK 2, SK 3 の ヘプタン表面積がアルゴン表面積より 2 割程度小さいこ とは，このことによるとして合理的説明される。

水蒸気表面積は処理しないシリカゲルでる小さな表面 積を与兄る場合があり，表面積をこれで決めるのは疑問 であるとの見解がある ${ }^{17)}$ 。しかしここで用いられたシリ カゲルは四塩化ケイ素の燃焼酸化により調整されたもの

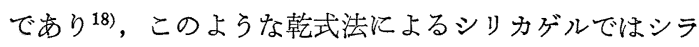
ノールの認められないことが赤外線吸収スペクトルの結 果からも知られている。このこと,拉よびこのような燃焼 酸化の過程で考光られる塩素の付着は蹯水性表面を形成 すると考兄られるから, 水蒸気表面積の小さいことは再 水和しない安定したシロキサンまたは付着塩素による表 面撥水性に帰因するとして説明可能である。表-1 に示 されるように, SK 2 とSK 3 の水蒸気表面積はアルゴ ン表面積と一致するし，アルゴン分子径は水とほぼ同じ であることを考慮すれば，水蒸気吸着も親水性表面に対 しては妥当な表面積を与えると考えうるであらう。これ に対し, 表面処理シリカゲルの水蒸気表面積は同じシリ カゲルのアルゴン表面積に比し著しく小さい。これはま た末処理シリカゲルの表面積に比しても著しく小さい。
これらのことは，水蒸気吸着での単分子層形成の段階で は, 親水基と置換した親油性付着基上には水蒸気は吸着 しないことを示していると考兄れる。これは従来の見 解とも一致する ${ }^{19)}$ 。

シリカゲルの表面シラノールに着目して全シラノール 数 $\mathrm{N}_{\mathrm{OH}}$ は次のように分けて考穴うるとする。

$$
\mathrm{N}_{\mathrm{OH}}=\mathrm{N}_{\mathrm{R}}+\mathrm{N}_{\mathrm{OH}}^{\mathrm{c}}+\mathrm{NOH}_{\mathrm{OH}}^{\mathrm{n}}+\mathrm{N}_{\mathrm{OH}}^{\mathrm{N}}
$$

ここに $\mathrm{N}_{\mathrm{R}}$ はアルコールと反応した表面水酸基数, $\mathrm{N}_{\mathrm{OH}}^{\mathrm{C}}$ は付着基で被覆されたミク口孔内市る未反応シラノー ルであり，未処理の状態ではへプタンの吸着も可能な表 面水酸基数, $\mathrm{N}_{\mathrm{OH}}^{\mathrm{n}}$ は未反応シテノールでヘプタンも吸 着可能な水酸基数, $\mathrm{N}_{\mathrm{OH}}^{\mathrm{N}}$ は吸着分子の大きさの相違か ら，アルゴンは吸着できるが，ヘプタンは吸着できない ような口径の毛管内にある表面水酸基数を表わす。これ らの単位はいずれも単位質量当たりの水酸基数である $\left(\mathrm{g}^{-1}\right)$ 。末処理シリカゲルのアルゴン表面積 $\Sigma_{\mathrm{SK}}^{\mathrm{Ar}}$ と水蒸 気表面積 $\sum_{\mathrm{SK}}^{\mathrm{H}_{2} \mathrm{O}}$ は表-1 に示すような $\mathrm{SK} 2, \mathrm{SK} 3$ と共 にほ汸一致するから，シテノールの分子断面積を $\sigma_{\mathrm{OH}}$ と とするとそれぞれ次式で示される。

$$
\sum_{\mathrm{SK}}^{\mathrm{Ar}}=\left(\mathrm{N}_{\mathrm{R}}+\mathrm{N}_{\mathrm{OH}}^{c}+\mathrm{N}_{\mathrm{OH}}^{\mathrm{n}}+\mathrm{N}_{\mathrm{OH}}^{\mathrm{N}}\right) \sigma_{\mathrm{OH}}=\sum_{\mathrm{SK}}^{\mathrm{H}_{2} \mathrm{O}}
$$$$
\text { またへプタン表面積 } \sum_{\mathrm{SK}}^{\mathrm{hep}} \text { は次式で表われる。 }
$$

$$
\sum_{\mathrm{SK}}^{\mathrm{hep}}=\left(\mathrm{N}_{\mathrm{R}}+\mathrm{N}_{\mathrm{OH}}^{\mathrm{n}}+\mathrm{N}_{\mathrm{OH}}^{\mathrm{c}}\right) \sigma_{\mathrm{OH}}
$$

処理シリカゲル付着基への吸着の難易は付着基とか吸 着質の性質で決まるが，アルゴンとへプタンはこれとは 無関係に吸着可能であり, 水蒸気以親油性付着基上に は吸着しないと考兄られる19)。この観点からすれば処 理シリカゲルのアルゴン, ヘプタン特よび水蒸気表面積 $\sum_{\mathrm{HRSK}}^{\mathrm{Ar}}, \sum_{\mathrm{HRSK}}^{\mathrm{hep}}, \sum_{\mathrm{HRSK}}^{\mathrm{H}_{2} \mathrm{O}}$ はそれぞれ次式で示される。

$$
\begin{aligned}
& \sum_{\mathrm{HRSK}}^{\mathrm{Ar}}=\left(\mathrm{N}_{\mathrm{OH}}^{\mathrm{n}}+\mathrm{N}_{\mathrm{OH}}^{\mathrm{N}}+\mathrm{N}_{\mathrm{R}}\right) \sigma_{\mathrm{OH}} \\
& \sum_{\mathrm{HRSSK}}^{\mathrm{hep}}=\left(\mathrm{N}_{\mathrm{R}}+\mathrm{N}_{\mathrm{OH}}^{\mathrm{n}}\right) \sigma_{\mathrm{OH}} \\
& \sum_{\mathrm{HRSK}}^{\mathrm{H}_{2} \mathrm{O}}=\left(\mathrm{N}_{\mathrm{OH}}^{\mathrm{n}}+\mathrm{N}_{\mathrm{OH}}^{\mathrm{N}}\right) \sigma_{\mathrm{OH}}
\end{aligned}
$$

(2)，(4) 式と（2），(6) 式执よび（3），(5) 式と から $\sum_{\mathrm{HRSK}}^{\mathrm{Ar}}, \sum_{\mathrm{HRSK}}^{\mathrm{hep}}, \sum_{\mathrm{HRSK}}^{\mathrm{H}_{2} \mathrm{O}}$ はそれぞれ

$$
\begin{aligned}
& \sum_{\mathrm{HRSK}}^{\mathrm{Ar}}=\sum_{\mathrm{SK}}^{\mathrm{Ar}}-\left(\mathrm{N}_{\mathrm{OH}}^{\mathrm{C}} / \mathrm{N}_{\mathrm{R}}\right) \sigma_{\mathrm{OH}} \cdot \mathrm{N}_{\mathrm{R}} \\
& \sum_{\mathrm{HRSK}}^{\mathrm{hep}}=\sum_{\mathrm{SK}}^{\mathrm{hep}}-\left(\mathrm{N}_{\mathrm{OH}}^{\mathrm{C}} / \mathrm{N}_{\mathrm{R}}\right) \sigma_{\mathrm{OH}} \cdot \mathrm{N}_{\mathrm{R}} \\
& \sum_{\mathrm{HRSK}}^{\mathrm{H}_{2} \mathrm{O}}=\sum_{\mathrm{SK}}^{\mathrm{H}_{2} \mathrm{O}}-\left(1+\mathrm{N}_{\mathrm{OH}}^{\mathrm{C}} / \mathrm{N}_{\mathrm{R}}\right) \sigma_{\mathrm{OH}} \cdot \mathrm{N}_{\mathrm{R}}
\end{aligned}
$$

で示されることになる。

4.2 .1 付着基数に対する処理シリカゲルの表面積

表-1 に示した処理シリカゲルへのアルゴン, ヘプタ ソ, 水蒸気表面積を付着基数につきプロットし, 図-2 に 示した。図示されるよらにこれらは未処理シリカゲルの 表面積を通る直線関倸が成立する。図-2 の直線の傾斜 はASK $2 \mathrm{n}$ につアルゴンで $22.5 \AA^{2}$, ヘプタンで $21.5 \AA^{2}$ とほ涪等しく, 水蒸気で $43.5 \AA^{2}$ となる。アル 

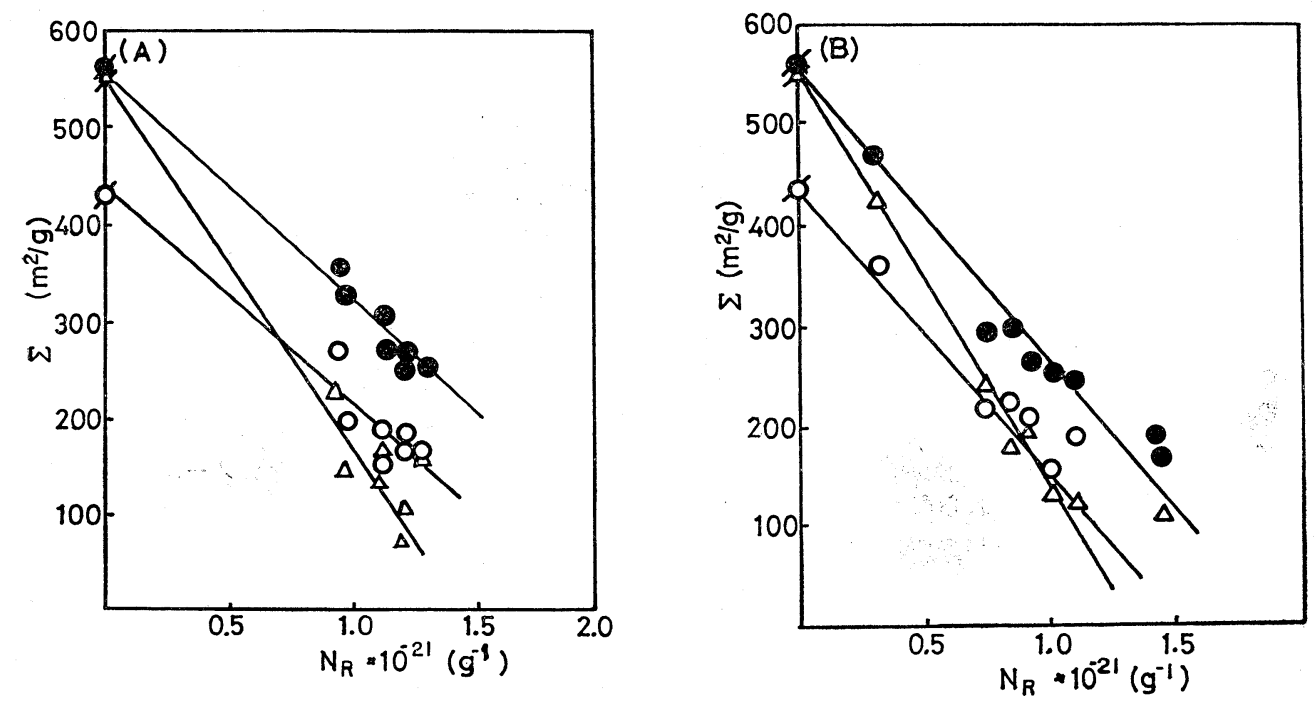

Fig. 2. The surface areas of surface-treated silica gels obtained from the adsorption isotherms of argon, water and $n$-heptane against the numbers of surface group

(A) Silica gels treated with $n$-pentanol; (B) Silica gels treated with benzyl alcohol

: Argon surface area; : Argon surface area of original silica gel

$\bigcirc: n$-Heptane surface area; $\sigma: n$-Heptane surface area of original silica gel

$\triangle:$ Water vapor surface area $\triangle \wedge:$ Water vapor surface area of original silica gel

ゴン表面積とヘプタン表面積の傾斜はいずれの試料でる 汪涪等しいのであるから（7)，（8)式の合䍿的であるこ とが認められるであろう。 $\left(\mathrm{N}_{\mathrm{OH}}^{\mathrm{C}} / \mathrm{N}_{\mathrm{R}}\right) \sigma_{\mathrm{OH}}$ はミクロ空孔に ある未反応シラノールで 1 コの付着基で和秝われ吸着点 となり得ない部分の面積を表わしている。これが $\mathrm{N}_{R}$ に 無関係に一定であることは，このような表面部分が均一 に分布していることを示して物り，このよらな意味でシ リカゲル表面はミクロ空孔の分布に関して規則性を特っ ていると考えられる。ASK $2 \mathrm{n}$ の $\left(\mathrm{N}_{\mathrm{OH}}^{\mathrm{C}} / \mathrm{N}_{\mathrm{R}}\right) \sigma_{\mathrm{OH}}=22 \AA^{2}$ とすると $\left(1+\mathrm{N}_{\mathrm{OH}}^{\mathrm{C}} / \mathrm{N}_{\mathrm{R}}\right) \sigma_{\mathrm{OH}}=38.5 \AA^{2}$ から $\sigma_{\mathrm{OH}}=16.5 \AA^{2}$, BZSK $3 \mathrm{n}$ の $\left(\mathrm{NOH}_{\mathrm{H}}^{\mathrm{C}} / \mathrm{N}_{\mathrm{R}}\right) \sigma_{\mathrm{OH}}=28 \AA^{2}$ とすると $\left(1+\mathrm{N}_{\mathrm{OH}}^{\mathrm{C}} /\right.$ $\left.\mathrm{N}_{\mathrm{R}}\right) \sigma_{\mathrm{OH}}=43.5 \AA^{2}$ から $\sigma_{\mathrm{OH}}=15.5 \AA^{2}$ となる。通常表 面シラノールの断面積は $\sigma_{\mathrm{OH}}=20 \AA^{2}$ と推定されている から ${ }^{20,21)}$ ，これらの值は幾分小さいが，汪湾妥当な值と 認めらるであろら。 $\sigma_{\mathrm{OH}}=16 \AA^{2}$ とすると, 付着基 1 二 で挌特われた吸着点とはなり得ない微小空孔内のシラノ 一ル数 $\mathrm{N}_{\mathrm{OH}}^{\mathrm{C}} / \mathrm{N}_{\mathrm{R}}$ はそれぞれ 1.33，1.81 となる。

このように付着基数を福々に変えた処理シリカゲルに ついての水蒸気，あるいは有機蒸気による表面積の検討 は余り報告されていない。Grade 12 シリカゲルをトり メチルクロロシランで処理したシリカゲル22), Grade 62 シリカゲルを2-プロパノールで処理したシリカゲル22) の $\mathrm{N}_{2}$ 表面積は図-3（1）（2）に示されるような直線関 係が認められる。なた, シリカゲルDをブタノールで処理

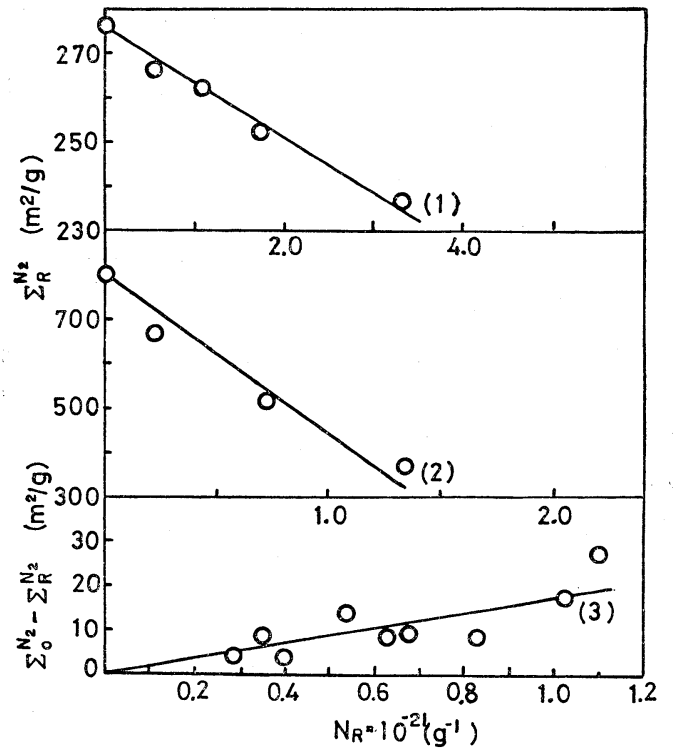

Fig. 3. The surface areas of surface-treated silica gels obtained from the adsorption isotherms of nitrogen against the numbers of surface group

(1) Silica gel ; Grade 12, treate with trimethylchlorosilane ${ }^{22}$ )

(2) Silica gel ; Grade 62, treated 2-with pentanol ${ }^{22)}$

(3) Silica gel; D treated with $n$-butanol ${ }^{23)}$ 
色材, 48 (1975)

したシリカゲル $\mathrm{N}_{2}$ の表面積23) と，未処理シリカゲルの 表面積との差も付着基数に対して直線関係を示す（図-3 (3))。 $\mathrm{N}_{2}$ とAr とでは多少の分子径の相違は考光られ るが，注涪同様に考兄られるから，これらの結果も(7) 式の成立することを示していると考兄られる。この直線 の傾斜は, SK 3 々同程度な大きな表面積を持つ Grade 12 シリカゲルでは同程度であるが, これより表面積の小 さな Grade 62 とかシリカゲルDでは著しく小さい。こ れはシリカゲル表面にある微小空孔は, 表面積が小にな ると表面安定化のために減少していることを示している と考えられる。調整法の異なるシリカゲルについて得ら れたこれらの結果からも(7)，(8)，(9)式はとれぞれ 妥当なものと認めらるであらら。また前述した例も含め て,このような直線性は付着基で拈括われ，吸着点とはな り得ない微小空孔内に岗る未反応シラノールは粉体表面 に均一に分布していることを示していると考㝋られる。

4.2.2 アルゴン, ヘプタン, 水蒸気表面積の相互関係 (4)，(5)，（6）式から次の関係が得られる。

$\sum_{\mathrm{HRSK}}^{\mathrm{Ar}}=\sum_{\mathrm{HRSK}}^{\text {hep }}+\sum_{\mathrm{HRSK}}^{\mathrm{H}_{2} \mathrm{O}}-\mathrm{N}_{\mathrm{OH}}^{\mathrm{n}}$

種々な炭素鎖を持つ直鎖飽和アルコール処理シリカゲ ルのヘプタン表面積と水蒸気表面積との和はアルゴン表 面積にほぼ等しいことを既報9) に指摘した。これはこ れらの処理で反応し得るシテノールは泀とんど反応して 特り， $\mathrm{N}_{\mathrm{OH}}^{\mathrm{n}} \simeq 0$ を示していると考它られる。処理シリカ ゲルのアルゴン表面積をとれぞれの試料につきへプタン 表面積に対しプロットすると図-4のように，未処理シ リカゲルも含めて $45^{\circ}$ の傾斜を持り直線となることが認 められる。同図には既報9 の結果も併示した。

(4)，(5) 式とから

$$
\begin{aligned}
& \sum_{\mathrm{HRSK}}^{\mathrm{Ar}}=\sum_{\mathrm{HRSK}}^{\mathrm{hep}}+\mathrm{N}_{\mathrm{OH}}^{\mathrm{N}} \sigma_{\mathrm{OH}} \\
& \sum_{\mathrm{SK}}^{\mathrm{Ar}}=\sum_{\mathrm{SK}}^{\mathrm{hep}}+\mathrm{N}_{\mathrm{OH}}^{\mathrm{N}} \sigma_{\mathrm{OH}}
\end{aligned}
$$

となるから, 前出した傾向はこの関係の成立することを 示するのであり, 特に（12）式の関係る含めて成立する ことは $\mathrm{N}_{\mathrm{OH}}^{\mathrm{N}} \sigma_{\mathrm{OH}}$ は付着基数 $\mathrm{N}_{\mathrm{R}}$ には無関係であること を示している。これは NNN は一定なシリカゲルでは一 定であることを示して和り，また $\mathrm{N}_{\mathrm{O}}^{\mathrm{C}}$ に数えられるシ ラノールはペンタノールまたはベンジルアルコールと反 応したとしても，これらはへプタンの入り得ない毛管内 に閉じこめられているからへプタン表面積には関与しな いことを示している。図-4 に供示されるように，種々 なアルコールで処理した場合も, ほぼ同様な傾向が得ら れる。これは上述した（11）式の成立することを示して いると共に, 表面は親水性表面と親油性表面との複合表 面から成るとした模型特よびこれを（1）式あるいは （10）式で表わすことの妥当性を示すと考兄られる。



Fig. 4. The argon surface areas against $n$-heptane surface areas

$\bigcirc$ : Silica gels treated with $n$-pentanol; : Silica gels treated with benzyl alcohol; $\odot$ : Silica gels treated with the various kinds of alcohols

(1) Methanol, (2) Ethanol, (3) $n$-Butanol,

(4) n-Hexanol, (5) n-Octanol, (6) n-Decanol, (7) n-Dodecanol, (8) n-Tetradecanol

4.2 .3 付着基で和特われる微小空孔内の未反応シテ ノールの面䅡

(7)，（8），（9）式は変形すると次式が得られる。 $\left(\mathrm{N}_{\mathrm{OH}}^{\mathrm{C}} / \mathrm{N}_{\mathrm{R}}\right) \sigma_{\mathrm{OH}}=\left(\sum_{\mathrm{SK}}^{\mathrm{Ar}}-\sum_{\mathrm{HRSK}}^{\mathrm{Ar}}\right) / \mathrm{N}_{\mathrm{R}}$

$\left(\mathrm{N}_{\mathrm{OH}}^{\mathrm{C}} / \mathrm{N}_{\mathrm{R}}\right) \sigma_{\mathrm{OH}}=\left(\sum_{\mathrm{SK}}^{\text {hep }}-\sum_{\mathrm{HRSK}}^{\mathrm{hep}}\right) / \mathrm{N}_{\mathrm{R}}$

$\left(\mathrm{N}_{\mathrm{OH}}^{\mathrm{C}} / \mathrm{N}_{\mathrm{R}}\right) \sigma_{\mathrm{OH}}=\left(\sum_{\mathrm{SK}}^{\mathrm{H}_{2} \mathrm{O}}-\sum_{\mathrm{HRSK}}^{\mathrm{H}_{2} \mathrm{O}}\right) / \mathrm{N}_{\mathrm{R}}-\sigma_{\mathrm{OH}}$

末処理, 処理試料のそれぞれの表面積拉よび付着基数 が測定されて招れば, これから付着基で拈扮われる微小 空孔内の未反応シラノールの占める面積を求めることが できる。しかし，この場合は各付着基に対する一点法に 相当するであろらから，その精度は付着基数を種々に変 えた前項の場合に比すれば落ちると考兄られる。 $\left(\mathrm{N}_{\mathrm{OH}}^{\mathrm{C}} /\right.$ $\left.\mathrm{N}_{\mathrm{R}}\right) \sigma_{\mathrm{OH}}$ は付着基の大ささにより異なると考えられるか ら，これを使用したアルコールまたはシランの分子断面 積に対してプロットし図-5 に示した。四示されるよう に, $13 \AA^{2}$ で横軸を切る直線関係が認められ, これとの 相関性が認められる。塩化ナオニルでシリカゲルを処 理し，その表面水酸基を塩素で置換した塩素化シリカゲ ルでは $\left(\mathrm{N}_{\mathrm{OH}}^{\mathrm{C}} / \mathrm{N}_{\mathrm{R}}\right) \sigma_{\mathrm{OH}} \simeq 4 \AA^{2}$ と著しく小さい。塩素の断 面積は $\mathrm{OH}$ 基の断面積にほぼ等しく $13 \AA^{2}$ と見積もら れる。分子径の同じもので置換した場合には, 通常付着 基で扮扮われるような微小径毛管も影響されず，したが 


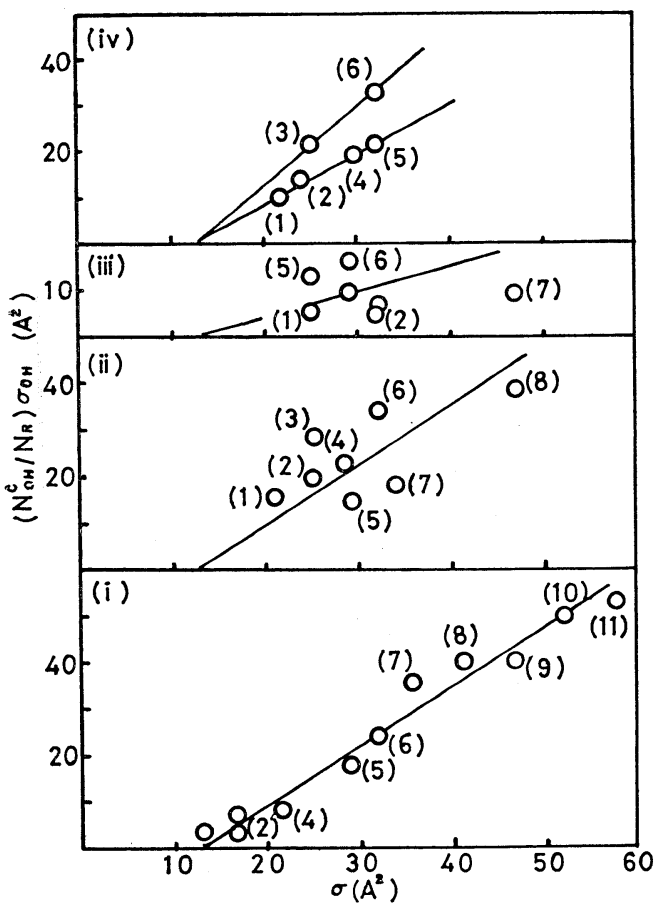

Fig. 5. $\left(\mathrm{N}_{\mathrm{OH}}^{\mathrm{C}} / \mathrm{N}_{\mathrm{R}}\right) \sigma_{\mathrm{OH}}$ against the molecular cross sectional area of the alcohol

(i) Silica gels treated with $n$-alcohols and with thionyl chloride

(1) Thionyl chloride ; (2) Methanol (silica gel, SK 2) ; (3) Methanol (silica gel, SK 3) ; (4) Ethanol(SK 2) ; (5) Butanol(SK 2) ; (6) Pentanol (SK 2) ; (7) Hexanol (SK 2) ; (8) Octanol (SK 3) ; (9) Decanol (SK 3) ; (10) Dodecanol (SK 2) ; (11) Tetradecanol (SK 3)

(ii) Silica gels; Grade 12, treated with alcohols and trimethylchlorosilane $\mathrm{e}^{22}$ )

(1) Ethylene glycol ; (2) $n$-Propanol ; (3) $i$ Propanol ; (4) i-Butanol ; (5) n-Butanol ; (6) Trimethylchlorosilane; (7) Phenethyl alcohol ; (8) $n$-Decanol

(iii) Silica gels ; Grade 62, treated with alcohols ${ }^{22}$ )

(1) n-Propanol ; (2) n-Amyl alcohol ; (3) $i$ Amyl alcohol ; (4) n-Butanol ; (5) $i$-Butanol ; (6) 2-Butanol ; (7) $n$-Decanol

(iv) Silica gels, W, treated with alcohol (water vapor adsorption) ${ }^{12}$ )

(1) $n$-Propanol ; (2) $i$-Propanol ; (3) $n$-Butanol ;

(4) $n$-Amyl alcohol ; (5) $i$-Amyl alcohol

ってこれに入り得る吸着質で測定される表面積は変化し ないであろう。実験結果はこれを示唆している。付着基 が大きくなれば， $\left(\mathrm{N}_{\mathrm{OH}}^{\mathrm{C}} / \mathrm{N}_{\mathrm{R}}\right) \sigma_{\mathrm{OH}}$ もそれに相当して大き くなるであららから, 多種類の付着基について求められ た $\left(\mathrm{N}_{\mathrm{OH}}^{\mathrm{C}} / \mathrm{N}_{\mathrm{R}}\right) \sigma_{\mathrm{OH}}$ がそれぞれの相当するアルコールの分
子断面積に対して, 二, 三の例外を除さほぼ直線関係を 示すのは妥当な傾向と考光られる。この場合も表面積の 小さいシリカゲル Grade 62 を処理した場合には, その 傾斜が小さく，Grade 62 表面には付着基で打沶われる 微小径空孔は少ないことを示して和り，前項での結果を 支持する。図-5 (2) はアルコール処理シリカゲルの水蒸 気表面積を用い（15）式から求められた結果である。こ の計算には $\sigma_{\mathrm{OH}}=15 \AA^{2}$ を用いた。これでも他と同様な 傾向が認められる。これも前出した関係の妥当性を示唆 するものであろうし，また親油基の上には亦分子は吸着 しないとした前出の模型の妥当性を示するのである。

これらの結果はシリカゲルのシラノールを（1）式の ように区別して表わすことは有意義であり， $\mathrm{N}_{R}$ は親油 性を, $\mathrm{N}_{\mathrm{OH}}^{\mathrm{N}}$ と $\mathrm{N}_{\mathrm{OH}}^{\mathrm{n}}$ は親水性表面を表わしていること が，それぞれの表面積との関連に和いて妥当と認められ た。したがって処理シリカゲルを親油性, 親水性に分け てそれぞれの蒸気吸着と対応させることは妥当と考えう るであろう。湿潤熱とか表面張力などの種々な物理量は 単位表面積当たりで表わす場合が多い。この場合, 表面 が親油性表面あるいは親水性表面のみで構成される場合 には Argon 表面積で求めれば良いが，処理シリカゲル のように親水, 親油性表面の複合表面から成る場合に は，これらの物理量をそれぞれの表面当たりに分離し， それぞれの表面積を正確に表わす蒸気で求められた表面 積を用いて表わすのが適当と考えられる。また付着基数 などの表示にも単位面積当たりで表示する場合が多い。 これには未処理シリカゲルの表面積を用い, $\Gamma_{\mathrm{R}}=\mathrm{N}_{\mathrm{R}} /$ $\sum \mathrm{S} \mathrm{S}=\mathrm{N}_{\mathrm{R}} /\left(\mathrm{N}_{\mathrm{R}}+\mathrm{N}_{\mathrm{OH}}^{\mathrm{C}}+\mathrm{N}_{\mathrm{OH}}^{\mathrm{N}}+\mathrm{N}_{\mathrm{OH}}^{\mathrm{n}}\right)$ で表わす場合と, 処 理シリカゲルの表面積を用いて $\Gamma_{\mathrm{R}}{ }^{\prime}=\mathrm{N}_{\mathrm{R}} / \sum_{\mathrm{HRSK}}^{\mathrm{Ar}}=\mathrm{N}_{\mathrm{R}} /$ $\left(\mathrm{N}_{\mathrm{R}}+\mathrm{N}_{\mathrm{OH}}^{\mathrm{n}}+\mathrm{N}_{\mathrm{OH}}^{\mathrm{N}}\right)$ で表わす場合とがある。前者は全シ ラノール数に対する反応率を検討するのに適当な表示で あろらし, 後者は付着基と未反応シラノールにより形成 されているシリカゲル処理後の表面での付着基の占める 割合（親油性表面と親水性表面との割合）などを検討す るのに適当な表示法と考えられる。

\section{3 毛管分布と毛管容積}

4.3.1 未処理シリカゲル SK 2 , SK 3 の毛管分布と 毛管容積

単分子吸着量を差し引いた毛管吸着量を比圧に対しプ •ットすると図-6 のようになる。SK 2 と SK 3 の毛管 吸着量は吸着質が水蒸気, ヘプタンの場合も共にほぼ一 致する。また表面積も前出したよらにそれぞれ一致する から, SK 2 と SK 3 とは粒径，毛管分布も含めた粉体 の基本的性質の同じシリカゲルとみなしうる(図-6(C), 表-1)。親水性である未処理シリカゲルは水, ヘプタン 

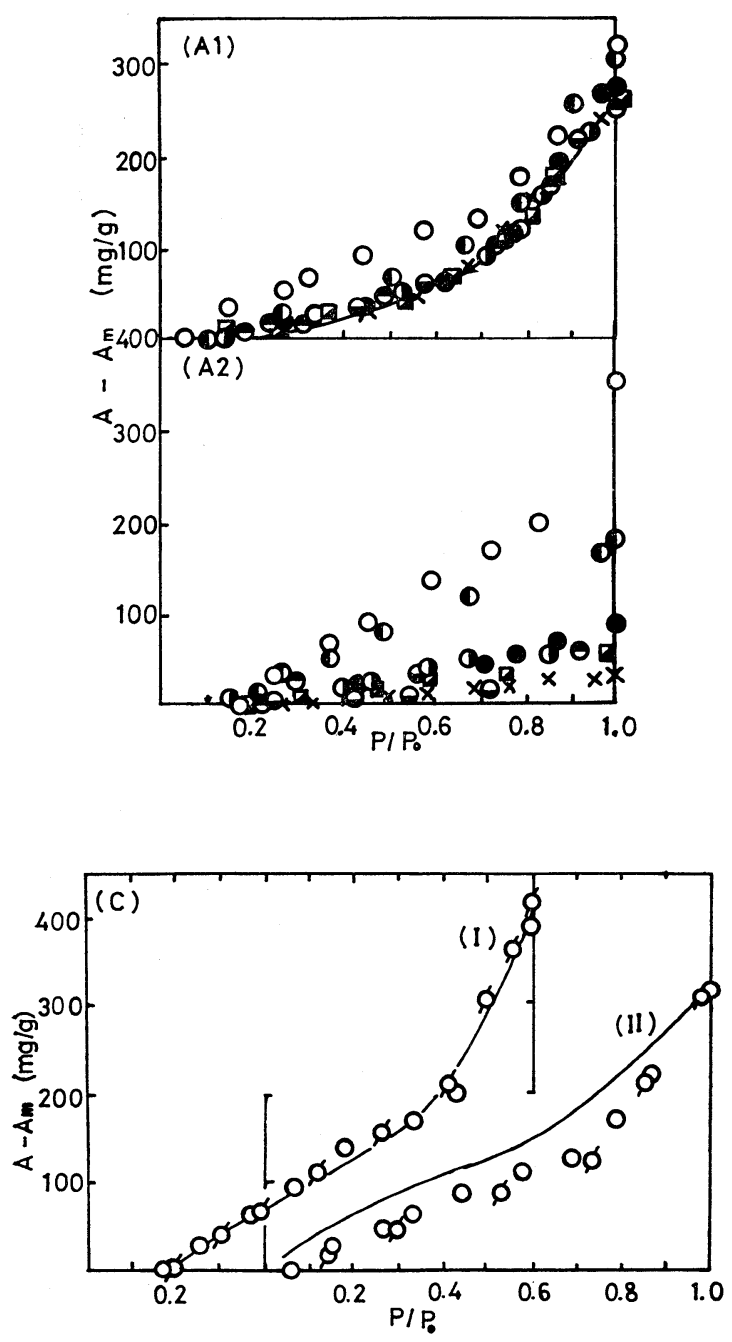

いずれの吸着質に対しても妥当な表面積を与え，また妥 当な飽和吸着量を与える。図 -5 (C) に示される水蒸気 吸着での比圧 $x_{1}$ に対する毛管凝縮量 $\left(a \mathrm{H}_{2} \mathrm{O}-a_{m}^{\mathrm{H}_{2} \mathrm{O}}\right)$ を毛 管半径と比圧に関する Kelvine 式24) を組み合わせた式

$$
\log x_{2}=\frac{\rho_{1} T_{1}}{\rho_{2} T_{2}} \frac{\gamma_{2} M_{2}}{\gamma_{1} M_{1}} \log x_{1}
$$

で換算し，ヘプタンの毛管凝縮曲線を求め同図（II）の 実線で示した。ここに $\rho, T, \gamma$ 扰よび $M$ はとれぞれ密 度, 温度, 表面張力括よび分子量を表わし，下ッキ添字 $1 ， 2$ はそれぞれ水，へプタンを表わす。これは $1.0>x_{2}>$ 0.1 また 0.2 または 0.2 のほぼ全比圧範团で $30 \mathrm{mg} / \mathrm{g}$ 程 度実測值より大きい。 $x_{2}=0.1 \sim 0.2$ は $11.0 \sim 15.7 \AA$ に 相当するので, これ以下の微小径毛管には, 水は吸着し らるがへプタンは入りえないとし，この毛管容を $V_{0} \mathrm{H}_{2} \mathrm{O}$

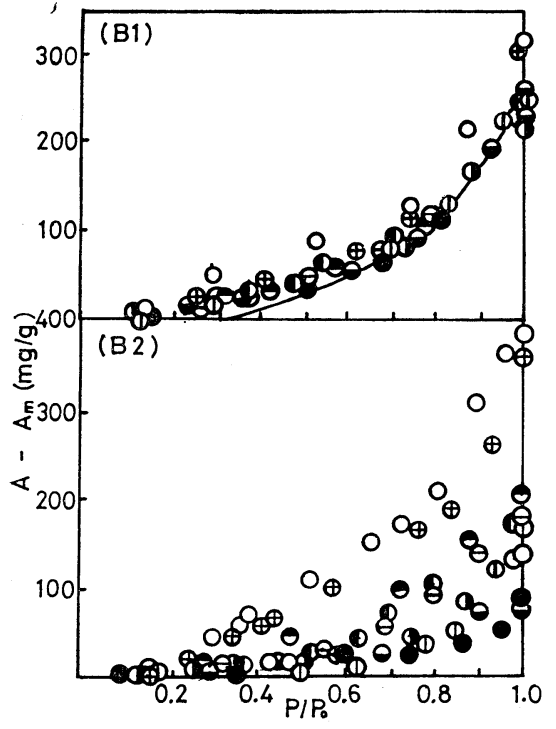

Fig. 6. Pore amount of original and surfacetreated silica gels against the relative pressure

(A 1) $n$-Heptane on silica gels treated with $n$-pentanol; (A 2) Water on silica gels treated with $n$-pentanol

$\bigcirc:$ SK 2 ; $:$ ASK $21 ;$ :ASK $22 ; \bullet:$ ASK $23 ; \ominus$ : ASK $24 ; \square:$ ASK 25 ; $:$ ASK $26 ; \times$ : HASK 2

(B 1) $n$-Heptane on silica gels treated with benzyl alcohol; (B 2) Water vapor on silica gels treated with benzyl alcohol

0 : SK 3 ; : BZSK 31 ; : BZSK 32 ; $\odot$ : BZSK 33 ; $:$ BZSK 34 ; : BZSK 35 ; $\odot$ : BZSK 35 $\left(\mathrm{H}_{2} \mathrm{O}\right)$; (1) : BZSK 35 (aq. acetone $5 \mathrm{hrs)} \mathrm{;} \ominus$ : BZSK 35 (aq. acetone $15 \mathrm{hrs)}$

(C) (I ) n-Heptane on original silica gel ; (C) Water vapor on an original silica gel

(II) $\bigcirc: \operatorname{SK} 2 ; \varnothing: \operatorname{SK} 3$

とすると比圧 $x_{1}$ での吸着容は $V \mathrm{H}_{2} \mathrm{O}$ は $V \mathrm{H}_{2} \mathrm{O}=V_{0} \mathrm{H}_{2} \mathrm{O}+$ $V\left(x_{1}\right)$ で示される。 $V\left(x_{1}\right)$ は $r=11.0 \sim 15.7 \AA$ の微少 空孔半径以上の半径を持ち, ヘプタン, 水のいずれも吸 着しうる毛管容積である。比圧 $x_{1}$ の水蒸気毛管凝縮量 $a^{\mathrm{H} 2 \mathrm{O}}$ はヘプタンの毛管凝縮量 $a^{\mathrm{h}} \mathrm{p}$ に換算し, 比圧 $x_{1}$ も相当するへプタン比圧 $x_{1 \rightarrow 2}$ に換算すると

$$
a_{\left(x_{1} \rightarrow x_{2}\right)}^{\text {hep }}=\left(\rho_{2} / \rho_{1}\right) a_{\left(x_{1}\right)}^{\mathrm{H}_{2} \mathrm{O}}=\rho_{2} V\left(x_{1}\right)+\rho_{2} V_{0} \mathrm{H}_{2} \mathrm{O}
$$

と示される。ここに $V_{0} \mathrm{H}_{2} \mathrm{O}$ は $x_{1 \rightarrow 2}=0.1 \sim 0.2$ で $V\left(x_{1}\right)$ $=0$ となる水分子は入れて, ヘプタンの入り得ない毛管 容である。

4.3 .2 処理シリカゲルのヘプタンによる毛管分布と 毛管容積

図-6（A 1)，（B1）に示されるように処理シリカゲル のヘプタン等温線は, 特に処理程度の低い試料以外では 

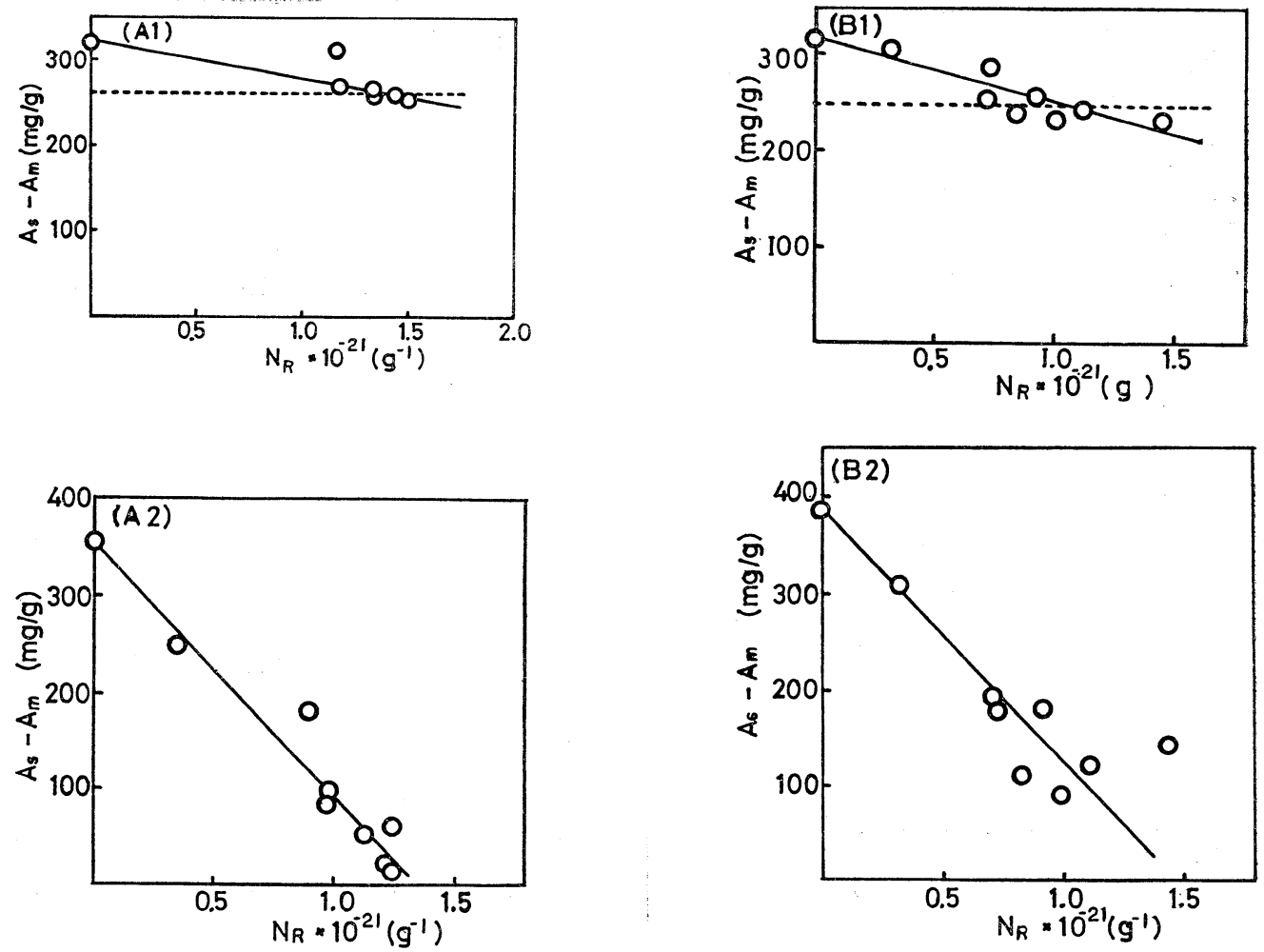

Fig. 7. The total amount of capillary pore against numbers of surface group

(A 1) $n$-Heptane on silica gels treated with $n$-pentanol ;

(A 2) Water vapor on silica gels treated with $n$-pentanol

(B 1) $n$-Heptane on silica gels treated with benzyl alcohol:

(B 2) Water vapor on silica gels treated with benzyl alcohol

付着基数如何にかかわらずほぼ一致している。これは示 される比圧に相当する毛管半径の範囲では表面処理によ る毛管分布の变化がないことを示していると考えられ る。未処理試料の毛管吸着量のみが処理試料のそれと異 なり，全比圧範囲でそれぞれ前者で $50 \mathrm{mg} / \mathrm{g}$ ，後者では $55 \mathrm{mg} / \mathrm{g}$ と幾分大きい。未処理試料の毛管凝縮量を基準 としてこれを補正した毛管吸着曲線を同図に併示した。 図示されるようにこれは処理試料のそれにはほぼ一致す る。したがって未処理, 処理シリカゲルのへプタン単分 子吸着量で示される相違はへプタンの入り得ない微小径 空孔の存在で説明されたが，これを除いてもな拉 50 $\mathrm{mg} / \mathrm{g}$ あるいは $55 \mathrm{mg} / \mathrm{g}$ 程度, 未処理シリカゲルのそれ より小さいのは，処理シリカゲルが付着基で遮げられて 入り得ない空孔を持っていることを示していると考えら れる。このような毛管は比較的小径である。また単分子 層形成には影響はなく，これより大きくしかるな特小径 であることを示している。飽和吸着量から笛分子吸着量 を差し引いた飽和毛管吸着量を付着基数に対してプロッ
トすると，图-7 に示されるようにペンタノール，ベン ジルアルコールのいずれで処理したシリカゲルです，そ れぞれの未処理シリカゲルのそれを通る直線関係を得る ことが認められる。ヘプタン飽和吸着量はペンタノール 処理シリカゲルでは付着基数 $1.0 \sim 1.3 \times 10^{21} \mathrm{~g}^{-1}$ の範 围ではほぼ $50 \mathrm{mg} / \mathrm{g}$ に相当するし, ベンジルアルコー ル処理シリカゲルでは付着基数 $0.7 \sim 1.5 \times 10^{21} \mathrm{~g}^{-1}$ では ほぼ $60 \mathrm{mg} / \mathrm{g}$ に相当する。これは図-6 (A1)，（B1)の 実線を得るのに未処理シリカゲルの毛管吸着量から差し 引く吸着量に一致する。このことは付着基が $0.7 \sim 1.5$ $\times 10^{21} \mathrm{~g}^{-1}$ の範囲では, 比圧 0.28 より飽和圧に相当す る毛管半径の領域でそれぞれの毛管容に変化のないこと を示していると考えられる。したがってこれは，この領 域での毛管分布が表面処理で変化していないことを示し ていると考兄らる。趇面処理は親油基が単分子層また はそれ以下の表面被覆とみなされるから ${ }^{1,2,4)}$, 未処理シ リカゲルの $50 \mathrm{mg} / \mathrm{g}$ あるいは $60 \mathrm{mg} / \mathrm{g}$ に相当する毛管 は微小空孔で，それ以下の表面被覆とみなされるか 
$ら^{1,2,4)}$ 未処理シリカゲルの $50 \mathrm{mg} / \mathrm{g}$ あるいは $60 \mathrm{mg} / \mathrm{g}$ に相当する毛管は微小径空孔であり，付着基の関与する 空孔で単分子層形成では影響されず，二層または三層形 成では付着基に影響されるような径の空孔であることが この場合にも認められた。

図-6（A1），（B2）に示されるように水による毛管吸 着量は付着基数の程度に応じ全比圧範囲で減少する。 プタンの検討から，これらの毛管半径領域での毛管容積 は処理程度により変化しないことが認められる。したが って水でのこの傾向は親油性でかつ疎水的でもある表面 への吸着と, その上への凝縮の困難さのためと考えられ る。毛管半径と比圧との関係を示す Kelvine 式の適応に 際しては, 通常接触角 $\theta=0$ すなわち $\cos \theta=1.0$ で固 体表面が凝縮液で完全にぬれるとして取扱われている が，部分的に眯水性である処理表面への水の接触角は必 ずしも $\cos \theta=1.0$ ではない。このよらな観点から毛管 凝縮について考察することは興味深い。

\section{4 湿潤熱}

表面積の検討から処理表面は親水性，親油性表面とか ら成り，単分子層形成の段階では，(1) 親油基には水蒸 気は吸着しない，(2) ヘプタンは親油, 親水性表面のい ずれにも吸着可能であるが，分子径の大きいことからこ れが入り得ない空孔内表面を持つとして, ほぼ妥当に説 明することができた。また湿潤熱は湿潤液の単分子層形 成の段階での発熱が支配的であるとして説明可能と認め られる ${ }^{8,9}$ のでこの観点から処理表面への水, ヘプタンに ついての湿潤熱を検討した。

処理微粉体の親水性部分の表面積を $\sum_{\mathrm{OH}}^{\mathrm{X}}$, 親油性部分 の表面積を $\Sigma_{\mathrm{R}}^{\mathrm{X}}$ とし，湿潤液 $\mathrm{X}$ の親水性表面への粉体 単位質量当たりの湿潤熱を $\Delta H_{i} \mathrm{OH}-\mathrm{x}$ ，親油性表面への それを $\Delta H_{i} \mathrm{R}-\mathrm{X}$ とすると，このような表面を持つ粉体 の表面積 $\sum \mathrm{HRSK}$ 牤よび湿潤熱 $\Delta H_{i} \mathrm{x}$ は

$$
\begin{aligned}
& \sum_{\mathrm{HRSK}}^{\mathrm{X}}=\sum_{\mathrm{R}}^{\mathrm{X}}+\sum_{\mathrm{OH}}^{\mathrm{X}} \\
& \Delta H_{i} \mathrm{x}=\Delta H_{i}^{\mathrm{R}-\mathrm{x}}+\Delta H_{i} \mathrm{OH}-\mathrm{x}
\end{aligned}
$$

で示される。これらの量の単位は単位質量当たりであ る。肩添字は湿潤液あるいは吸着質を表わす。親水性表 面, 親油性表面への湿潤液Xの単位面積当たりの湿潤熱 を各々 $\Delta h_{i} \mathrm{OH}-\mathrm{x}, \Delta h_{i}^{\mathrm{R}-\mathrm{x}}$ とすると, $\Delta H_{i} \mathrm{x}$ は

$$
\Delta H_{i} \mathrm{x}=\Delta h_{i} \mathrm{R}-\mathrm{x} \sum_{\mathrm{R}}^{\mathrm{x}}+\Delta h_{i} \mathrm{OH}-\mathrm{x} \sum_{\mathrm{O}}^{\mathrm{x}}
$$

で示される。処理シリカゲルの水蒸気表面積は $\sum_{\mathrm{H}}^{\mathrm{H}_{2} \mathrm{O}}$ $=\left(\mathrm{N}_{\mathrm{OH}}^{\mathrm{n}}+\mathrm{N}_{\mathrm{OH}}^{\mathrm{N}}\right) \sigma_{\mathrm{OH}}$ で表わされる。すなわち処理シリカ ゲルへの水の吸着は単分子層形成の段階では親水性表面 にのみ吸着するとして合理的に説明されることが認めら れ ${ }^{8,9,25)}$, 前項でも検討された。したがって付着基を持 たない未処理シリカゲルでは，(16) 式は $\sum_{\mathrm{HRSK}}^{\mathrm{H}_{2} \mathrm{O}}=\Sigma_{\mathrm{OH}}^{\mathrm{H}_{2} \mathrm{O}}$
$=\sum_{\mathrm{SK}}^{\mathrm{H}_{2} \mathrm{O}}$ となる。湿潤熱に奇与するのは単分子層形成ま での吸着の際に示す発熱であり, 多重層領域での発熱は 小さいから, 処理シリカゲルへの水の湿潤熱 $\Delta \mathrm{H}_{i} \mathrm{H}_{2} \mathrm{O}$ は 次式で近似できる。

$$
\Delta H_{i} \mathrm{H}_{2} \mathrm{O}=\Delta h_{i} \mathrm{OH}-\mathrm{H}_{2} \mathrm{O} \sum_{\mathrm{OH}}^{\mathrm{H}}
$$

前報9,25) で $\Delta \mathrm{H}_{i} \mathrm{H}_{2} \mathrm{O}$ を $\sum_{\mathrm{HRSK}}^{\mathrm{H}_{2} \mathrm{O}}$ に対し四示するとほ ぼ直線となることが認められ，この直線の傾斜から $\Delta h_{i} \mathrm{OH}-\mathrm{H}_{2} \mathrm{O}=290 \mathrm{erg} / \mathrm{cm}^{2}$ となり，これからシラノール と水との相互作用を求めると $3.05 \times 10^{-13} \mathrm{erg}$ となる。 シラノール数を種々に変えたシリカゲルへの水の湿潤 熱26)を同様にプロットすると直線となることが認めら れ，シテノールと水との相互作用は $3.4 \times 10^{-13} \mathrm{erg}$ と評 価され良く一致するので，上述した取扱いととの相互作 用の示す值の妥当性が認められだ9 。

つぎに未処理，処理シリカゲルへのープタンの湿潤熱 $\Delta H_{i}{ }^{\text {hep }}$ から（18）式を検討した。（5)，（17）式とから 処理シリカゲルのヘプタン表面積は $\sum_{\mathrm{HRSK}}^{\mathrm{hep}}=\left(\mathrm{N}_{\mathrm{R}}+\right.$ $\left.\mathrm{N}_{\mathrm{OH}}^{\mathrm{n}}\right) \sigma_{\mathrm{OH}}=\sum_{\mathrm{R}}^{\text {hep }}+\sum_{\mathrm{OH}}^{\text {hep }}$ となるから $\sum_{\mathrm{R}}^{\text {hep }} \sum_{\mathrm{R}}^{\text {hep }}=$ $\mathrm{N}_{\mathrm{R}} \sigma_{\mathrm{OH}}$ から求めると $\sum_{\mathrm{OH}}^{\mathrm{hep}}$ は上述した関係から求める ことができる。 $\sigma_{\mathrm{OH}}$ は前報9,25)で求められた $\sigma_{\mathrm{OH}}=15 \AA^{2}$ を用いた。 $\Delta h_{i}$ OH-hep には未処理シリカゲルへのへプタ ンの湿潤熱を求め, 表-3 の結果から $\Delta H_{i} \mathrm{hep}-\Delta h_{i} \mathrm{OH}-\mathrm{hep}$

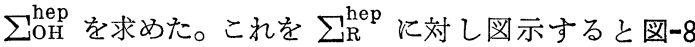

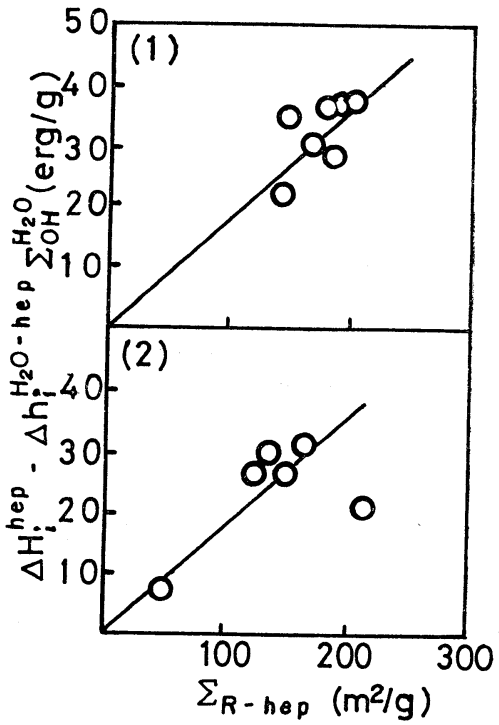

Fig. 8. The heat of wetting of $n$-heptane on hydrophobic surface of surface-treated silica gels against the surface areas of the hydrophobic surface

(1) Silica gels treated with $n$-pentanol

(2) Silica gels treated with benzyl alcohol 
のようになる。図示されるように匟直線関係の成立す ることが認められ，

$$
\Delta H_{i}{ }^{\text {hep }}-\Delta h_{i}{ }^{\mathrm{OH}-\mathrm{hep}} \sum_{\mathrm{OH}}^{\mathrm{hep}}=\Delta h_{i}^{\mathrm{R}-\mathrm{hep}} \sum_{\mathrm{R}}^{\mathrm{hep}}
$$

の関係の妥当なことが認められた。この傾斜からペンタ ノール処理シリカゲルでは $\Delta h_{i}{ }^{\mathrm{R}-\mathrm{hep}}=160 \mathrm{erg} / \mathrm{cm}^{2}$, へ ソジルアルコール処理シリカゲルでは $\Delta h_{i}{ }^{\mathrm{R}-\mathrm{hep}}=180$ $\mathrm{erg} / \mathrm{cm}^{2}$ となる。 $\Delta_{i}^{\mathrm{R}-\mathrm{hep}}$ は付着基とへプタンとの相互 作用による発熱量であるから親油性表面についての湿潤 熱と考えられる。親油性表面である graphon へのへプ タンの湿潤熱は， $112 \mathrm{erg} / \mathrm{cm}^{2}$ 27)，C，F が表面を形成し 低エネルギー表面であるテフロン28)ではこれより低い $58 \mathrm{erg} / \mathrm{cm}^{2}$ である ${ }^{27)}$ 。有極性表面を持つエアロシルあ るいは $\mathrm{TiO}_{2}$ でもほぼ変らず $144 \sim 120 \mathrm{erg} / \mathrm{cm}^{2}$ とされ ている27)。基体表面の踈面度にもよるが，ヘプタン表面 積は一般に $\mathrm{N}_{2}$ 表面積より小さい值を示すことを考える ならば，この程度の相違は単位表面積への換算に際して $\mathrm{N}_{2}$ 表面積を用いたのか，ヘプタン表面積を用いたのか の相違によると考えるならば説明可能である。これらの 取扱いで $\sum_{\mathrm{R}}^{\text {hep }}=\mathrm{N}_{\mathrm{R}} \sigma_{\mathrm{OH}}$ で表わしているから（20）式は

$$
\Delta h_{i}{ }^{\mathrm{R}-\mathrm{hep}} \sigma_{\mathrm{OH}}=\left(\Delta H_{i} \mathrm{hep}-\Delta h_{i}{ }^{\mathrm{OH}-\mathrm{hep}} \sum_{\mathrm{OH}}^{\mathrm{hep}}\right) / \mathrm{N}_{\mathrm{R}}
$$

と変形することができる。種々なアルコールで処理され たシリカゲルへのヘプタンの湿潤熱から付着基の炭素と, ヘプタンの炭素との間の相互作用の平均を $\Delta h \mathrm{C}_{\mathrm{R}}-\mathrm{C}_{\mathrm{hep}}$ と すると（単位は erg/a pair)

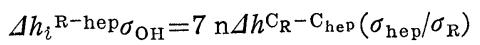

ここに $\mathrm{n}$ は付着基中の炭素数を表わし， $\sigma_{\mathrm{hep}}, \sigma_{\mathrm{R}}$ はそれ ぞれヘプタン技よび付着基の分子断面積である。 $\sigma_{\mathrm{hep}} / \sigma_{\mathrm{R}}$ はへプタン分子が何コの付着基に対応するかを近似的に 表わす係数である。これを図-6 の直線の傾斜 $\Delta h_{i}{ }^{\mathrm{R}-\mathrm{hep}}$ から $\Delta h \mathrm{C}_{\mathrm{R}}-\mathrm{C}_{\mathrm{hep}}$ を(21) 式で求めるとペンタノール処理 シリカゲルでは $\Delta h \mathrm{C}_{\mathrm{pent}_{\text {t }}}-\mathrm{C}_{\mathrm{hep}}=5.05 \times 10^{-15} \mathrm{erg}$, ベンジ ルアルコール処理シリカゲルでは $\Delta h^{\mathrm{C}_{\mathrm{benz}}}-\mathrm{C}_{\mathrm{hep}}=4.61 \times$ $10^{-15} \mathrm{erg}$ である。これらは前報で種々な直鎖飽和アル コール処理シリカゲルにつき求められた $\Delta h^{\mathrm{C}-\mathrm{C}}=6.7 \times$ $10^{-15} \mathrm{erg}$ と同程度である。芳香環を持つ場合などでは, なお検討の余地はあるであろうが，このようにして求め られた付着基中の炭素と湿潤液分子中の炭素との間の相 互作用に関する值は，な牧妥当なるのと認めらるであろ う。したがってこのような親水性, 親油性表面の複合表 面への湿潤熱は，それぞれの表面に対する湿潤液との相 互作用として求めるのが適当と考光られる。

この報文を微粉体の表面処理に関する基礎的研究 （第 19 報）とする.

前報（第 18 報）宇津木 弘・西村成與・堀越英生： 材料, 22, 673 (1973)

\section{文献}

1）宇津木 弘, 渡辺昭輝, 伊藤昆逸, 西村成興 : 日 化, 91，431（1970）

2) 宇津木 弘, 西村成興, 加野哲郎 : 日化 (1972), 1557：材料, 21，528（1972）

3）宇津木 弘, 西村成興, 堀越英生 : 材料, 22, 678 (1973)

4) 宇津木 弘, 堀越英生, 松沢敏晴 : 材料, 23, 541 (1974)

5）宇津木 弘：日化, (1972), 2237.

6) 宇津木 弘, 西村成與：色材, 46, 73 (1973)

7）宇津木 弘, 堀越英生：日化, (1972), 2244.

8）宇津木 弘, 西村成興：日化, 92, 759 (1971); 材料, 20, 737 (1971)

9）宇津木 弘, 西村成興, 島崎光雄 : 日化 (1972), 2007; 宇津木 弘, 西村成興：材料, 21, 534(1972)

10) M. M. Dubinin: "Surface Area Determination, Proc. Inst. Symp. (1969)” Publ. 1970, ed. by D. H. Everett, Butterworths, London, p. 123.

11) A. V. Kiselev : "Hydrophobic Surface," ed. by F. M. Fowkes, Acad. Press, New York (1969), p. 88.

12）宮田謙一：日化，87，116（1966）

13）宇津木 弘：日化，88，279，598(1967）; 宇津木 弘, 高村吉彦：日化，88，604（1967）

14) H. K. Livingston : J. Am. Chem. Soc., 66, 569 (1944)

15) K. Kodera, Y. Onishi : J. Jap. Chem. Soc., 32, 356 (1959)

16) S. J. Gregg, K. S. W. Sing : “Adsorption, Surface Area and Porosity", Acad. Press, New York (1967), p. 82.

17) G. D. Young : J. Colloid Sci., 13, 67 (1958)

18） R. N. McDonald : J. Am. Chem. Soc., 79, 851 (1957)

19) G. Mertens, J. J. Fripiat : J. Colloid \& Interface Sci., 42, 169 (1973)

20) M. L. Hair : "Infrared Spectroscopy in Surface Chemistry”, Masceu Decker, Inc., New York (1967), p. 122.

21) A. N. Sidrov : Russ. J. Phys. Chem. Engl. Transl., 30, 935 (1956)

22) J. B. Sorrell, R. Rowan : Analyt. Chem., 42, 1712 (1970)

23) C. C. Ballard, E. C. Broge, R. K. Iler, D. S. St. John, J. McWhorter : J. Phys. Chem., 65, 20 (1961)

24) A. W. Adamsion : "Physical Chemistry of Surfaces”, Inte:sci. Publ., New York (1967), p. 637.

25）宇津木 弘, 西村成興 : 材料, 22, 680 (1973)

26) J. A. G. Taylor, I. A. Hockey : J. Phys. Chem., 70, 2169 (1973)

27) J. J. Chessick, A. C. Zettlemoyer : “Adv. in Catalysis, Vol.XI,” Acad. Press, New York (1959), p. $2 \hat{j} 3$.

28） A. W. Adanıson : 前出文献（24）の p. 363 . 